\title{
Reviuw Beberapa Bioaktivitas dan Senyawa Kimia Organisme Laut untuk Kefarmasian
}

\author{
Laode Rijai \\ Pharmaceutical Research and Development Laboratory of PHARMACA TROPIS \\ Fakultas Farmasi, Universitas Mulawarman, SAMARINDA, KALIMANTAN TIMUR, \\ INDONESIA \\ *Email: najwankhanrjai@yahoo.co.id
}

\begin{abstract}
The sea as a habitat for organisms, is very characteristic and extreme compared to the terrestrial environment. This extreme environment allows the metabolic processes of living things within to become characteristic and produce a number of secondary metabolites that are characteristic for defense. Secondary metabolites are certain compounds that are only possessed by certain orgasms, and these class of compounds are very valuable for pharmaceuticals such as raw materials for medicines, nutraceuticals, cosmetics, to medical devices. A number of types of compounds with biological activity very important for pharmaceuticals originating from marine organisms are (a) Cytotoxic activities sourced from Sinularin compounds, Crassin Acetate, Cytarabine, Fludarabine, Aplysistatin, Geranylhydroquinone, Asperidol (b) Cardiovascular activities for (i) Activities for Cardiotonic namely compounds Laminin, Octopamine, Saxitoxin, Autonomium Chlorides (ii) Activities for Hypotensive namely Spongosine, Doridosine, Aaptameine, Hymenin (c) Marine Toxin, namely compounds of the group Polytoxin, such as Palytoxin; Red Tide Toxin compounds such as Tetrodotoxin, Brevetoxin in the form of $\mathrm{Pb} \mathrm{Tx}-1$ and $\mathrm{Pb} \mathrm{Ts}-1$; and Ciguatera Toxin groups, namely Ciguatoxin (d) Antimicrobial Activity such as Zonarol, Prepacifenol, Polyhalo-3-Butene-2-one; Tetrabromo-2-heptanone; 2-Cyano-4,5dibromopyrrole, Aeroplysinin (+) and (-); Eunicin (e) Activities for Antibiotics namely Okadaic Acid, Acanthfolicin, Norhalichondrin A; and (f) Active Miscellaneous for Pharmaceuticals, namely Latrunculin A and B; Kainic Acid, Domoic Acid, Vidarabine, Aplysinopsin, Barettin, Nereistotoxin and 28-Deoxyzoanthenamine compounds.
\end{abstract}

Key words: Senyawa Kimia Organisme Laut untuk Farmasi, Bioaktivitas untuk Farmasi

\begin{abstract}
ABSTRAK
Laut sebagai habitat organisme, sangat karakteristik dan ekstrim dibandingkan lingkungan daratan. Lingkungan ekstrim tersebut memungkinkan proses metabolisme mahluk hidup yang ada di dalamnya menjadi karakteristik dan menghasilkan sejumlah metabolit sekunder yang karakteristik untuk pertahanan. Metabolit sekunder adalah senyawa tertentu yang hanya dimiliki oleh orgnisme tertentu, dan golongan senyawa tersebut sangat bernilai untuk kefarmasian antara lain sebagai bahan baku untuk obat, nutraceutical, kosmetik, hingga alat kesehatan. Sejumlah jenis senyawa dengan aktivitas biologi sangat penting untuk kefarmasian yang bersumber dari organisme laut adalah (a) Aktivitas sitotoksik bersumber dari senyawa Sinularin, Crassin Acetate, Cytarabine, Fludarabine, Aplysistatin, Geranylhydroquinone, Asperidol (b) Aktivitas Cardiovascular untuk (i) Aktivitas untuk
\end{abstract}


Cardiotonic yaitu senyawa Laminin, Octopamine, Saxitoxin, Autonomium Chlorides (ii) Aktivitas untuk Hypotensive yaitu Spongosine, Doridosine, Aaptameine, Hymenin (c) Marine Toxin yaitu senyawa golongan Polytoxin, seperti Palytoxin; senyawa golongan Red Tide Toxin seperti Tetrodotoxin, Brevetoxin berupa $\mathrm{Pb} \mathrm{Tx}-1$ dan $\mathrm{Pb}$ Ts-1; serta golongan Ciguatera Toxin yaitu Ciguatoxin (d) Aktivitas Antimikrobial seperti Zonarol, Prepacifenol, Polyhalo-3-Butene-2-one; Tetrabromo-2-heptanone; 2-Cyano-4,5dibromopyrrole, Aeroplysinin (+) dan (-); Eunicin (e) Aktivitas untuk Antibiotic yaitu Okadaic Acid, Acanthfolicin, Norhalichondrin A; serta (f) Miscellaneous Aktif untuk Kefarmasian yaitu Latrunculin A dan B; Kainic Acid, Domoic Acid, Vidarabine, Aplysinopsin, Barettin, Nereistotoxin serta senyawa 28-Deoxyzoanthenamine.

Kata Kunci: Senyawa Kimia Organisme Laut untuk Farmasi, Bioaktivitas untuk Farmasi

DOI: https://doi.org/10.25026/jsk.v2i1.119

\section{PENDAHULUAN}

Lingkungan hidup organisme laut sangat karakteristik dan ekstrim sehingga metabolisme yang terjadi pada setiap organisme laut juga karakteristik dan esktrim dan akhirnya berpotensi menghasilkan jenis senyawa kimia yang banyak dan berbeda antara organisme satu dan linnya serta senyawa kimia tersebut memiliki sifat fisiko-kimia yang karakteristik (Martin et al., 1997). Karakteristik organisme laut yang sangat tampak adalah cara hidup yang beranekaragam antara jenis organisme satu dan lainnya. Karena itu pengelompokan jenis organisme laut tidak berdasarkan ukuran tubuh atau fisik organisme tersebut melainkan berdasarkan cara hidup setiap jenis oragnisme terhadap lingkungannya (Nybakken, 1993). Organisme laut pada umumnya tidak memiliki sistem sekresi seperti halnya mamalia, karena itu termasuk organisme yang memiliki keragaman jenis metabolit sekunder yang banyak, karena metabolit sekunder adalah golongan senyawa hasil metabolisme sekunder yang tersimpan dalam sel dan jaringan suatu organisme, karen organisme tersebut tidak memiliki sistem sekresi yang sempurna. Karena itu, organisme hayati yang banyak memiliki metabolit sekunder paling banyak dan beragama jenis adalah tumbuhan, hewan tingkat rendah, dan termasuk seluruh organisme laut. Sejumlah organisme tersebut akhirnya sangat berpotensi dalam bidang kefarmasian dan telah diketahui sejaka manusia ada. Organisme paling dikenal berpotensi kefarmasian adalah tumbuhan sehingga dikenal tumbuhan obat, sedangkan untuk hewan obat belum populer.

Kemanfaatan senyawa kimia sangat dipengaruhi bentuk struktur molekulnya, dan setiap molekul memiliki kemanfaatan lebih dari satu potensi sehingga keragaman jenis senyawa akan memberikan kemanfaatan yang beragam pula dan sangat banyak terutama kemanfaatan untuk mamalia dan lingkungannya (Dougherty et al., 2006). Senyawa kimia yang beragam jenis dan strukturnya adalah metabolit sekunder, sedangkan metabolit primer tidak demikian halnya karena merupakan polimer yang tersusun oleh monomer metabolit sekunder. Organisme laut yang pada umumnya tidak memiliki sistem sekresi yang sempurna seperti halnya mamalia akan memiliki keragaman senyawa kimia yang banyak terutama metabolit sekunder yang merupakan senyawa hasil metabolisme yang tersimpan secara baik dalam sel dan jaringan hayati karena tidak tersekresi. 
Keragaman senyawa kandungan organisme laut yang sangat banyak tersebut akan memiliki kemanfaatan yang banyak pula, baik itu kegunaan yang berasal dari satu jenis senyawa, maupun dari banyak senyawa. Ilustrasi yang dapat dilakukan, jika suatu organisme mengandung 5 jenis senyawa metabolisme sekunder potensial dan setiap jenis senyawa tersebut memiliki 5 kemanfaatan, maka organisme tersebut akan memiliki 25 jenis kegunaan atau kemanfaatan. Karena itu potensi organisme laut pada umumnya sangat beragam serta berbeda dengan organisme daratan termasuk potensi kefarmasian untuk obat, nutraceuticals (makanan fungsional, suplemen, makanan medis, makanan rekayasa genetik), kosmetik dan potensi lainnya. Organisme laut pada umumnya tidak memiliki sistem sekresi sempurna tersebut, seperti halnya mamalia, sehingga memiliki kandungan metabolit sekunder yang banyak dan sangat beragam jenisnya. Keadaan ini menjadikan organisme laut sangat potensial dalam bidang farmasi khususnya terkait kegunaannya sebagai obat, nutraceuticals hingga kosmetik (Baslow, 1969 dan Tursch, 1978).

Indonesia berpotensi sebagai penghasil senyawa bermanfaat dalam bidang kefarmasian, karena selain memiliki hutan dengan keanekaraman hayati yang melimpah, juga memiliki wilayah laut sangat luas dan di dalamnya terdapat keanekaragaman hayati yang melimpah sebagai daerah tropis, baik itu tumbuhan maupun hewan yang karakteristik pada setiap lingkungan laut. Keadaan ini merupakan potensi dalam bidang farmasi sebagai sumber bahan baku yang potensial untuk obat, nutraceutical, dan kosmetik. Keragaman organisme laut dengan keragaman cara hidup akan menyebabkan keragaman jenis senyawa kimia kandungannya, khususnya metabolit sekunder; dan akhirnya memiliki potensi kefarmasian yang beragam pula. Karena itu, pengelompokan biota laut berdasarkan sifat atau cara hidup pada lingkungan laut yang karakteristik dan bukan karena ukuran fisik tubuh (Nybakken, 1993).

\section{METODE}

Artikel ini merupakan reviuw dengan metode studi literatur. Pengkajian literatur menggunakan metode analisis komperehensif hingga sintetik. Literatur sebagai sumber informasi terdiri dari beberapa buku referens serta artikel ilmiah. Informasi yang dikaji secara literatur adalah beberapa potensi kefarmasian yang dapat dimiliki oleh sejumlah organisme laut, serta jenis senyawa kimia yang memiliki potensi kefarmasian tersebut. Terkait dengan perihal tersebut kemanfaatan artikel ini adalah (a) pengetahuan tentang beberapa potensi kefarmasian yang dimiliki organisme laut dan beberapa organisme laut yang berpotensi kefarmasian (b) kemudahan penelusuran kegunaan suatu organisme laut dengan berpedoman pada potensi senyawa kimia yang terkandung dalam organisme tersebut.

\section{HASIL DAN PEMBAHASAN}

Materi kajian artikel ini adalah sejumlah aktivitas biologi dan senyawa kimia organisme laut yang berpotensi kefarmasian. Beberapa aktivitas biologi dan senyawa kimia organisme laut yang berpotensi kefarmasian tersebut adalah:

\section{A. Cytotoxic atau Antineoplastic Agents}

Sitotoksik adalah aktivitas biologi suatu senyawa kimia yang memiliki sifat fisiko-kimia yang dapat merusak sel mamalia. Aktivitas biologi ini oleh keilmuan farmasi menjadikan suatu potensi untuk membunuh sel kanker dengan memanfaatkan toksisitasnya yang kuat sehingga disebut dengan sitotoksik. Penggunaan senyawa sitotoksik untuk membunuh sel kanker menjadi suatu metode terapi yang akhirnya disebut dengan Chemoterapi yaitu penggunaan 
kimia berbahaya atau toksik untuk terapi dengan mekanisme kerja senyawa membunuh sel kanker sebagai suatu kasus penyakit. Istilah Chemoterapi sebenarnya sangat tidak relevan dengan keilmuan kimia, karena seluruh kegiatan terapi dengan penggunakan bahan kimia, terapi tersebut merupakan kemoterapi atau terapi penggunaan senyawa kimia.

Dua Lembaga Riset dunia paling terkenal terkait dengan penggunaan sitotoksik sebagai terapi kanker yaitu NCI (National Cancer Institute) dan National Sea Grant Office (NSGO). Kedua lembaga riset tersebut telah menemukan sekitar seratus (100) senyawa murni dan semi murni dari organisme laut yang terbukti menghambat sejumlah pertumbuhan kanker secara in vivo atau praklinik. Kelompok senyawa yang telah terkarakterisasi dengan baik sebagai Cytotoxic adalah Cembranes, Macrolides,
Depeptides, dan Miscellanous compounds. Ciri khas senyawa sitotkisk memiliki gugus lakton, akan tetapi terdapat senyawa sitotoksik tidak memiliki gugus lakton. Beberapa contoh senyawa sitotoksik lakton dan non-lakton ditunjukkan berikut ini.

\section{a. Senyawa Sitotoksik Lakton}

Beberapa senyawa sitotoksik yang memiliki gugus lakton dari kelompok Cembranoids, yaitu terdiri dari hingga 14 siklik diterpen yang banyak ditemukan dalam berbagai karang lunak (sofs corals). Sejumlah Cembranoid compounds tersebut telah diisolasi dan dikarakterisasi dan umumnya merupakan exocyclic lactone. Beberapa contoh Cembranoids adalah sinularin, Crassin acetate, cytarabine (Ara-C), fludarabine, dan aplysistatin.

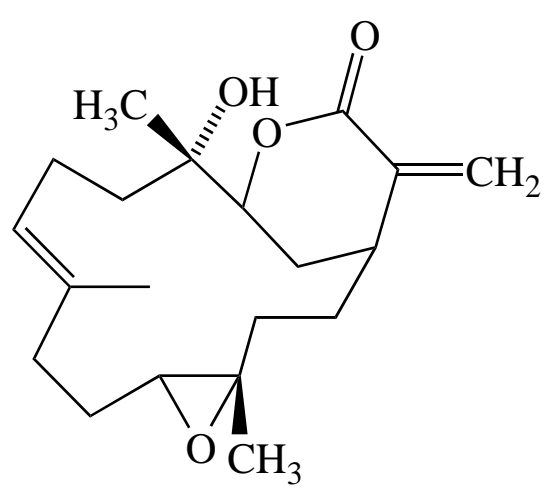

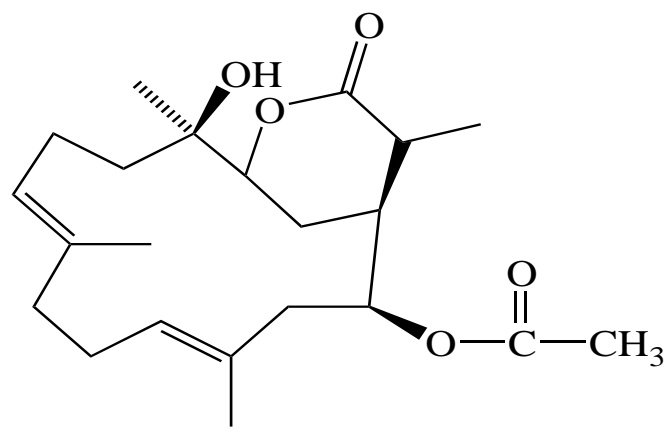

Crassin Acetate

Sinularin<smiles></smiles>

Cytarabine 
<smiles>Nc1nc(F)nc2c1ncn2C1OC(CO)C(O)C1O</smiles>

Fludarabine<smiles>C=C1OCC2OC3(C)CCC(Br)C(C)(C)C3CC=C12</smiles>

Aplysistatin

Gambar 1. Beberapa Struktur Senyawa Lakton Sitotoksik dari Organisme laut

Sinularin ditemukan dari Sinularia flexibilis telah digunakan sebagai obat kanker; Crassin acetate diperoleh dari Caribbean gorgonian Pseudoplexaura porosa inert terhadap sistem mamalian hewan tetapi sangat sitotoksik terhadap sel kanker leukemia manusia. Selanjuntnya Cytarabine yang bersinonim dengan Ara-C; Alexan, Arabitin; Aracytine, Cytarbel; Cytosar; Erpalfa; Iretin; Udicil; U-19920; CHX3311; $\quad$ Aracytidine; $\quad \beta$-Citosine Arabinoside; ditemukan dalam Sponges, dan telah digunakan sebagai obat leukimia. Untuk Fludarabine bersinonim dengan 2-Fluorovidarabine dan 2-F-Ara A yang juga ditemukan dalam Sponge telah digunakan sebagai antineoplastic agent; Aplysistatin yang ditemukan dari Aplysia angasi yang juga merupakan antineoplastic agents.

Selanjutnya, terdapat senyawa sitotoksik tidak mengandung gugus lakton yaitu senyawa

non-Lactone Cembranoid, tidak mengandung lakton tetapi sitotoksik. Senyawa yang termasuk non-lactone cembranoids adalah Geranylhydroquinone yang ditemukan dalam fraksi Kloform Aplidium $S p$, dengan kemanfaatan sangat baik untuk pengobatan kanker leukemia dan mammary carcinoma; Asperidol, dari Gorgonian coral juga memiliki aktivitas sitotoksik meskipun tidak memiliki gugus lakton.<smiles>CC(C)=CCCC(C)=CCc1cc(O)ccc1O</smiles><smiles>C=C(C)C(CC/C(C)=C/CCC1OC1C)C(O)/C=C(\CC)CO</smiles>

Asperidol

Gambar 2. Senyawa Sitotoksik Non Lakton dari Organisme laut 


\section{B. Senyawa Organisme Laut untuk Cardiovascular}

Sejumlah organisme laut, juga telah ditemukan senyawa yang memiliki aktivitas yang terkait untuk pengobatan jantung. Keadaan menarik adalah terdapat sejumlah senyawa yang memiliki aktivitas sebagai obat jantung; dan beberapa senyawa tersebut juga terbukti sebagai antibiotik dan antineoplastik agents. Aktivitas biologi untuk obat jantung atau Cardiovascular diklasifikasi dalam dua kategori yaitu Cardiotonic dan Hypotensive.

\section{a. Senyawa untuk Cardiotonic}

Senyawa Cardiotonics yaitu suatu senyawa yang secara in vivo maupun in vitro memiliki aktivitas inotropic terhadap seluruh atau sebagian penyakit jantung. Secara, kimia senyawa yang termasuk Cardiotonic dari organisme laut terdiri dari Marine peptides dan Marin glycosides.

Marine peptida ditemukan pada Coclenterates sperti spesies Anthopleura xanthogrammica memproduksi

Anthopleurins A, B, dan C yang diketahui sebagai AP-B, C dan Anthopleura elegantissima memproduksi AP-C. Ketiga Anthopleurins tersebut, hanya AP-A yang telah dilaporkan paling berpotensi memiliki aktivitas Cardiotonic yang diisolasi dari spesies yang berbeda. Selanjutnya, Anemonia toxin II yang juga disebut Cardiotoxin-II, ATX-II yang diisolasi dari Anemonia sulcata yang terdiri dari 47 asam amino, memiliki kemiripan dengan AP-A. Peptida Anthopleurin-A (AP-A) pada redisu 38 merupakan Alanin, sedangkan Anemonia Toxin-II (ATX-II) adalah Lysine. Senyawa lain yang memiliki aktivitas cardiotonic dari Marine peptides adalah laminim, octopamine, dan autonomium chloride yang ditemukan dalam Alga Laminaria angustata. Octopamine ditemukan pada Octopus vulgaris,
Octopus macropus, dan Eledone moschata. Selanjutnya, juga senyawa Saxitoxin yang bersinonim Mussel poison, Clam poison, Paralyitic Sellfish poison, Gonyoulax toxin dan STX, berguna untuk neurotoxin yang ditemukan pada dinoflagellates Gonyaulax catenella atau G. tamarensis. Kegunaan lain Saxitoxin menurunkan tekanan darah.

Marine Glycosides, secara umum ada dua tipe yaitu tersulfasi dan non tersulfasi. Holothurins dan Astrsaponins contoh Marine glycosides yang memiliki aktivitas Cardiotoxic. Holothurins suatu residu aglycone yang ditemukan pada famili Holothuroidae dari phylum Echinodermata. Selanjutnya Astrosaponins adalah Marine glycosides dari bintang laut famili Asteroidae. Fakta menunjukkan bahwa kedua Marine glycosides tersebut dapat menghambat $\mathrm{Na}^{+}, \mathrm{K}^{+}, \mathrm{Mg}^{+2}$ dan enzim ATP ase, dan Holothurins lebih kuat menghambat $\mathrm{Na}^{+}$, $\mathrm{K}^{+}, \mathrm{Mg}^{+2}$ dan enzim ATP ase.

Beberapa struktur senyawa Marine peptides dan Marin Glycoside untuk Cardiotonic ditunjukkan pada Gambar 3.

\section{b. Senyawa untuk Hypotensive}

Senyawa untuk Hypotensive adalah senyawa kimia yang dapat menurunkan tekanan darah. Beberapa senyawa tersebut telah ditemukan dari berbagai Marine Organism, yang digolongkan dalam dua kategori, yaitu (a) Marine nucleosides dan (b) Hypotensive peptides serta senyawa lain yang juga memiliki aktivitas untuk Hypotensive.

\section{1) Senyawa Marine Nucleosides}

Nucleosida adalah gabungan purin atau pyrimidine dengan glycosidic seperti adenosine, thymidine; sedangkan jika penambahan ester fosfat dari suatu nucleoside disebut dengan nukleotida yaitu 5'-guanylic acid; 3'-cytidylic acid. Contoh senyawa nukelosida, Spongosine dari Caribbean Sponge Cryptotethia 
crypta yang digunakan sebagai obat jantung koroner; Doridosine penurun tekanan darah; dan 5'-deoxy-5iodobericidin menghambat kerja enzim<smiles>NCC(O)c1ccc(O)cc1</smiles>

adenosine kinase. Beberapa contoh senyawa Hypotensive golongan Marine Nucleosides ditunjukkan pada Gambar 4.
Octopamine<smiles>CNC[C@@H](O)c1ccc(O)c(O)c1</smiles>

Adrenaline<smiles>CC(=O)OCCC(C)(C)C</smiles><smiles>CN(C)CCc1cc(Br)c(O)c(Br)c1</smiles><smiles>N=C1N[C@@H]2[C@@H](COC(N)=O)NC(=N)C23CCC(O)N13</smiles>

Saxitoxin

Acetylcholine

Gambar 3. Beberapa senyawa Marin peptedies dari Organisme Laut yang memiliki Aktivitas Cardiotonic<smiles>CC(O)C1CC2C(N=CN2C2OC(CO)C(O)C2O)C(N)=N1</smiles>

Spongosine<smiles>NC1Nc2c(ncn2C2OC(CO)C(O)C2O)C(=O)C1N</smiles>

Doridosine

Gambar 4. Senyawa Marine glycosides untuk Hypotensive dari Organisme Laut

\section{2). Senyawa Peptides dan Lainnya untuk Hypotensive}

Selanjutnya, senyawa peprides untuk Hypotensive, Aaptamine memiliki efek hypotensive serta menurunkan toksisitas dalam sistem metabolisme;
Hymenin, Urotensins I dan II (U I, U II). Hymenin bersumber dari Hymeniacidon aldis, dengan manfaat yang sama dengan Aaptamine; Urotensins I dan II (U I, U II) merupakan polypeptide bersumber dari Giltichthys miralitis dan juga ikan 
Catostomus commersoni, dengan manfaat sebagai penurun tekanan darah, dengan mekanisme kerja pada pelebaran

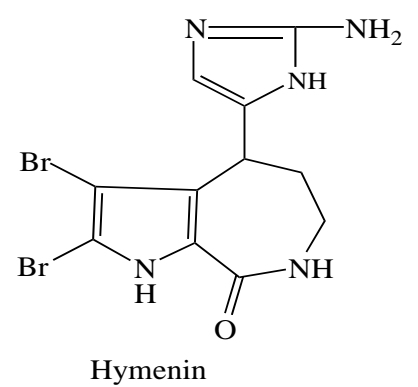

pembuluh darah. Gambar 5 berikut contoh senyawa peptide dan lainnya dari organisme laut.

\section{Marine Toxins.}

Senyawa Marin biotoxin telah ditemukan dari berbagai organisme laut dalam bentuk ekstrak dan senyawa semi murni sekitar tahun 1960 - 1971. Sejumlah senyawa tersebut memiliki struktur kimia yang sangat kompleks, tetapi memiliki toksisitas yang tinggi sehingga disebut dengan Marine Toxins. Para ahli Kimia Laut akhirnya berhasil mengisolasi dan mengkarakterisasis sejumlah senyawa Marine Toxin dengan struktur kimia yang sangat kompleks tersebut. Marine Toxins diklasifikasi dalam tiga kategori yaitu (a) Polytoxin (b) Red-Tide Toxins dan (c) Ciguatera toxins.

\section{a. Polytoxins}

Polytoxin, pertama kali ditemukan di laut Pasific tahun 1971 dan 1974. Struktur molekulnya merupakan poli dengan rumus kimia $\mathbf{C}_{129} \mathbf{H}_{223} \mathbf{N}_{3} \mathrm{O}_{54}$. Senyawa ini berwujud padat amorphous hygroscopic dan berpotensi sebagai untuk mengatasi jantung koroner. Senyawa polutoxins banyak ditemukan dari koral Zanathid genus Polythoa yang banyak ditemukan di laut Caribia dan Pacific. Umumnya merupakan toksin non protein. Salah conoth polytoxin yang diketahui strukturnya secara baik adalah Palytoxin
(C51-55) hemiasetal, yang merupakan polytoxin yang telah memiliki data yang lengkap. Kegunaan utamanya untuk jantung koroner, anti-anginal Chemoterapi Agents

\section{b. Red Tide Toxins}

Kelompok senyawa ini ditemukan pada Ptychodiscus brevis yang juga disebut Gymnodinium breve; Protogonyaulax catenella yang diketahui sebagai Gaunyaulax catenella dan Protogonyalulax tamarensis. Senyawa yang termasuk Red Tide Toxins adalah Saxitoxins (STXs), Tetrodotoxin, dan Brevetoxin. Tetrodotoxin, bersinonim dengan fugu poison, Maculotoxin, Spheroidine, Taricahatoxin, Tetrodontoxin, dan TTX. Tetrodotoxin ditemukan dalam berbagai hati sejumlah ikan besar seperti spesies dari Tetraodontidae terutama Spheroides rubripes. Selain itu, juga ditemukan pada Ikan Buntal (Tetradou species). Kegunaannya dapat mengendalikan perubahan $\mathrm{Na}^{+}$menjadi $\mathrm{K}^{+}$yang sangat cepat. Senyawa Red Tide Toxin lainnya adalah Brevetoxin yang ditemukan dari Phycodiscus brevis dan sekarang Brevetoxin dikenal sebagai PbTx dengan nomenklatur $P$. brevis toxins. 


\section{c. Ciguatera Toxins}

Kelompok Ciguatera Toxins seperti Ciguatoxin (CTX) dengan nama istilah Ciguatoxin, pertama kali merupakan racun yang ditimbulkan setelah konsumsi keran laut. Racun ciguatoxin juga bersumber dari alga hijau. Ciguatoxin ditemukan Gymnothorax javanicus, pada berbagai coral dan juga ikan sepertin Lutjanus bohar. Manfaat Ciguartoxin adalah mengatasi masalah jantung, syaraf, serta gastro-intestinal dengan dosis rendah. Senyawa lainnya yang termasuk Ciguatera toxin adalah Maitotoxin dengan sinonim MTX yang ditemukan dari Dinoflagellate Gambierdiscus toxicus.

\section{Senyawa Antimikroba untuk Obat}

Senyawa antimikroba untuk obat adalah spesifik untuk jamur dan bakteri; sedangkan untuk virus lebih spesifik karena virus adalah bukan mahluk hidup. Sumber senyawa antimikroba adalah sumberdaya alam dan sintetik atau semi sintetik. Organisme laut salah sumber antimikroba yang telah banyak diktehui. Senyawa antimikroba organisme laut telah banyak diisolasi secara dari berbagai spesies Alga hijau, alga merah, coral, dan sponge. Beberapa senyawa antimiroba yang telah dikarakterisasi dari organisme laut adalah Zonarol dari Dictyopteris zonaroides (alga hijau); Prepactiphenol dari Laurencia Pacifica dan Laurencia filformis (Alga merah); Polyhalo-3butene-2-one dari Asparagopsis taxiformis yaitu spesies lain Alga merah; Tetrabromo-2-Heptanone dari Alga merah Bonnemaisonia hemifera; 2Cyano-4,5-dibromopyrrole dari Agelas oroides; Aeroplysinin-1(+) dan Aeroplysinis-1(-) dari Verongia aerophoba merupakan sepesies dari Sponge; Euncin ditemukan dari Eunicia mammosa yang merupakan Coral. Gambar 6 menunjukkan beberap senyawa Antimikroba yang ditemukan dari organisme laut.<smiles>[R]C([R])=CC(=O)C([R])[R]</smiles>

Polyhalo-3-Butene-2-One (R1 - R4 adalah Halo Atom)<smiles>CC1(Cl)CC(O)C2(CC1Br)C(C)(C)C(Br)=CC1OC12C</smiles>

Prepaciphenol<smiles>CC1CCC2C(C)(C)CCCC2(C)C1Cc1cc(O)ccc1O</smiles>

Zonarol<smiles>N#Cc1cc(Br)c(Br)[nH]1</smiles>

2-Cyano-4,5-dibromopyrrole<smiles>C[CH]C=CC(Br)(Br)C(=O)C(Br)Br</smiles>

Tetrabromo-2-heptane 


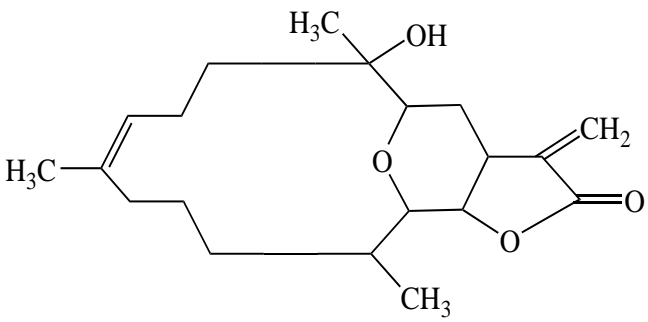

Eunicin<smiles>COC1=C(Br)CC(O)(CC#N)C(O)=C1Br</smiles>

Aeroplysinin-1(-)<smiles>COC1=C(Br)C(O)C(O)(CC#N)C=C1Br</smiles>

Aeroplysinin-1(+)

Gambar 6. Beberapa Senyawa Antimikrobial dari Organisme Laut

Senyawa antimikroba, secara struktur mengandung unsur halogen seperti Brom, serta sianida yang menunjukkan memiliki toksisitas. Secara struktur senyawa halogen kurang baik sebagai antibiotik karena toksisitasnya kecuali dengan doses ketat.

\section{E. Senyawa Antibiotik Penting dari Organisme laut}

Senyawa antibiotik umumnya merupakan semi-sintetik setalah ditemukan dari organisme yaitu untuk produksi pada jumlah yang banyak. Antibiotik dari organisme laut juga telah banyak ditemukan seperti Okadaic Acid dengan sinonim Halochondrine A yang ditemukan dari Halichondria okadai (okadai atau malanodocia); Acanthifolicin dari Pandaros acanthifolium

(Sponge);

Norhalichondrin A juga dari Halichondria okadai (Sponge) yang juga aktif sebagai antitumor. Struktur senyawa antibiotik dari organisme laut cukup kompleks dan menunjukkan senyawa karbamat yang memiliki aktivitas yang sesuai untuk suatu antibiotik.

\section{F. Antiinflammatory dan Antispasmodic Organisme Laut}

Beberapa senyawa antiinflamasi dari organisme laut adalah Dendalone-3hydroxybuyrate dari Pylospongia dendyi atau Spong; 6-n-Tridecyl salicylic acid dari Caulocystic cephalomithos atau Alga coklat; Flexibilide dari Sinularia flexibilitis merupakan Karang Lunak (Soft Coral), dan Monalide dari spesies Luffariella variabilis atau Sponge. Selanjutnya, senyawa organisme laut yang memiliki aktivitas Antispasmodic agents adalah Flustramine A dan B dari Flustra foliaceae; Tetradoctoxin Spheroides rubripes atau semua ikan.

\section{G. Miscellaneous \\ Kefarmasian}

Sejumlah senyawa yang memiliki activitas untuk kefarmasian telah diisolasi dan dikarakterisasi dari organisme laut. Beberapa di antaranya adalah Latruncullins; Kainic Acid; Domoic Acid; Vidarabine; Aplysinopsin; 28Deoxyzoanthenamine; Barettin; Nereistotoxin; dan Conotoxin.

Latruncullins (LAT) diperoleh dari Latrunculia magnifica dan Cromodoris elisabethina dan juga pada Spongia mycofijiensis (Fijian Sponge). Kegunaannya lebih banyak terkait penelitian natural product chemistry atau material sciences. Kainic Acid dari Digenea simplex yang berptensi untuk mengatasi kejang (neurol) serta anthemintic (Nematode). Domoic Acid dari Chondria armata (alga merah) juga sebagai material sains. Vidarabine hasil 
culture Streptomyces antibioticus yang potensial sebagai antineoplastic agents; Aplysinopsin dari Verongia spengelii (Sponge kuning) dam juga dari Astroides calicularis (Anthozoan) yang berpotensi sebagai obat Leukimia; 28Deoxyzoanthenamine dari Zonathus $\mathrm{sp}$ yang memiliki anelgesik yang kuat dan juga sebagai antiinflamasi. Selanjutnya, senyawa lainnya adalah Barettin dari Geodia beretti yang berguna untuk stimulan pada usus halus; Nereistotoxin dari cacing laut atau Lumbriconeris heteropoda sebagai insektisida; Conotoxins dari Conus geographus. Berikut adalah beberapa senyawa Miscellaneous yang memiliki aktivitas potensial untuk kefarmasian.<smiles></smiles>

Ltrunculin A<smiles>CN1C(=N)NC(=O)/C1=C\c1c[nH]c2ccccc12</smiles>

Aplysinopsin

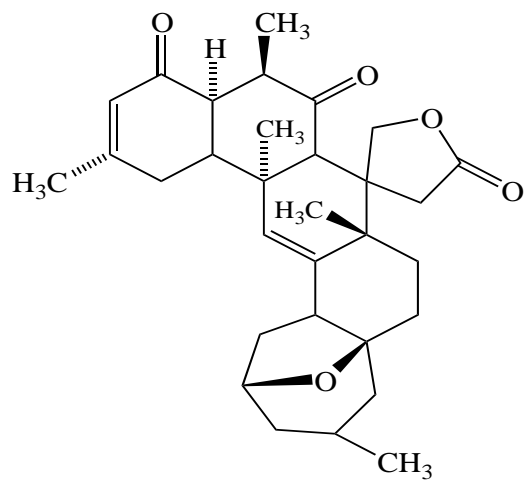

28-Deoxyzoanthenamine<smiles>C=C(C)[C@H]1CNC(C(=O)O)[C@@H]1CC(=O)O</smiles>

Kainic Acid<smiles>C/C(=C/C=C/[C@@H](C)C(=O)O)C1CN[C@H](C(=O)O)C1CC(=O)O</smiles>

Demoic Acid<smiles>Nc1ncnc2c1ncn2C1OC2C(O)C(O)C1C2O</smiles>

Vidarabine<smiles>O=C1N/C(=C\c2c[nH]c3cc(Br)ccc23)C(=O)N2CCCC12</smiles><smiles>CN(C)C1CSSC1</smiles>

Nereistotoxin

Gambar 7. Beberapa senyawa Miscellaneous Berpotensi Kefarmasian dari Organisme Laut 


\section{KESIMPULAN}

1. Organisme Laut mengandung sejumlah senyawa yang memiliki aktivitas biologi sangat penting untuk kefarmasian yaitu (a) Aktivitas sitotoksik bersumber dari senyawa Sinularin, Crassin Acetate, Cytarabine, Fludarabine, Aplysistatin, Geranylhydroquinone, Asperidol (b) Aktivitas Cardiovascular untuk (i) Aktivitas untuk Cardiotonic yaitu senyawa Laminin, Octopamine, Saxitoxin, Autonomium Chlorides (ii) Aktivitas untuk Hypotensive yaitu Spongosine, Doridosine, Aaptameine, Hymenin (c) Marine Toxin yaitu senyawa golongan Polytoxin, seperti Palytoxin; senyawa golongan Red Tide Toxin seperti Tetrodotoxin, Brevetoxin berupa $\mathrm{Pb}$ Tx-1 dan $\mathrm{Pb}$ Ts-1; serta golongan Ciguatera Toxin yaitu Ciguatoxin (d) Aktivitas Antimikrobial seperti Zonarol, Prepacifenol, Polyhalo-3Butene-2-one; Tetrabromo-2heptanone; 2-Cyano-4,5dibromopyrrole, Aeroplysinin (+) dan (-); Eunicin (e) Aktivitas untuk Antibiotic yaitu Okadaic Acid, Acanthfolicin, Norhalichondrin A; serta (f) Miscellaneous Aktif untuk Kefarmasian yaitu Latrunculin A dan B; Kainic Acid, Domoic Acid, Vidarabine, Aplysinopsin, Barettin, Nereistotoxin serta senyawa 28Deoxyzoanthenamine,

2. Organisme Laut penghasil seluruh senyawa berpotensi kefarmasian tersebut umumnya bersumber dari non ikan yaitu tumbuhan dan coral

\section{REKOMENDASI}

Indonesia yang memiliki laut yang luas dengan keanekaraman hayati dan non hayati yang melimpah, mengandung sejumlah senyawa potensial untuk kefarmasian. Karena itu terdapat peluang penggalian dan pemanfaatan sumberdaya laut non ikan untuk kefarmasian. Artikel ini dapat menjadi pedoman terhadap pencarian senyawa potensial untuk kefarmasian sesuai dengan berbagai aktivitas biologi beserta jenis senyawanya untuk menjadi rujukan pemanfaatan sumberdaya alam laut non ikan dalam bidang kefarmasian yaitu untuk obat, nutraceutical, kosmetik, hingga alat kesehatan.

\section{DAFTAR PUSTAKA}

[1]. Baslow, M.H. 1969. Marine Pharmaceuticals. Williams \& Wilkinis, Baltimore.

[2]. Blunt, J. W. and M.H.G. Munro. 1997. A Data Base of the Literature on Marine Natural Products Chemistry, University of Canterbury.

[3]. Dougherty, D.A. and E. V. Anslyn. 2006. Modern Physical Organic Chemistry, University Sciences Books.

[4]. Hoppe, H. A. and T. Levring. 1982. Marine Algae in Pharmaceuticals Sciences. Vol. 2. De Gruyter, Berlin.

[5]. Jimenez, C. 2018. Marine Natural Products in Medicinal Chemistry. ACS. Publisher.

[6]. Levinthon, J. S. 2019. Marine Biology: Function, Biodiversity, Ecology, Oxford University Press. 5 Edition

[7]. Martin, L. and G. Padila. 1973. Marine Pharmacognosy. Academic Press, New York

[8]. Nigrelli, R. F. 1960. Biochemistry and Pharmacology of Compounds Derived from Marine Organisms. Ann. NY Acad. Sc. New York.

[9]. Newman, D. J. and Cragg, D. M. 2016. Natural Products as Sources of New Drugs from 1981 to 2014. The American Chemical Society 
and American Society of Pharmacognosy Publisher.

[10]. Nybakken, J. W. 1993. Marine Biology: An Ecological Approach. Harper collins College Publisher.
[11]. Trusch, B. J. 1978. Chemistry of Marine Natural Products. Vol. 2. Academic Press. New York. 